\title{
Factor analysis as a tool to estimate association among individual proteins and other milk components with casein micelle size and cheese yield
}

\author{
[Análise fatorial como ferramenta para estimar a associação entre proteínas individuais e outros \\ componentes do leite com o tamanho das micelas de caseína e massa seca de queijo] \\ D.R. Freitas ${ }^{1}$, F.N. Souza ${ }^{1}$, L.M. Fonseca ${ }^{2}$, C.V.G. Ladeira ${ }^{1,3}$, V.P.F. Santos ${ }^{4}$, S.A. Diniz ${ }^{1}$, \\ M.X. Silva', J.P.A. Haddad², M.M.O.P. Cerqueira ${ }^{2}$ \\ ${ }^{1}$ Aluno de pós-graduação - Escola de Veterinária - UFMG - Belo Horizonte, MG \\ ${ }^{2}$ Escola de Veterinária - UFMG - Belo Horizonte, MG \\ ${ }^{3}$ Empresa de Pesquisa Agropecuária de Minas Gerais - Belo Horizonte, MG \\ ${ }^{4}$ Aluna de graduação - Escola de Veterinária - UFMG - Belo Horizonte, MG
}

\begin{abstract}
The present study attempted to identify individual milk proteins and other milk components that are associated with casein micelle size (CMS) and dry matter cheese yield (DMCY) using factor analysis. Here, we used 140 bulk tank milk samples from different farms. Milk composition was determined using a Fourier transform infrared equipament. The individual milk proteins were $\left(\alpha_{S}\right.$-casein, $\beta$-casein, $\kappa$-casein, $\beta$-lactoglobulin and $\alpha$-lactoalbumin) measured by their electrophoretic profile. The CMS was estimated by photon correlation spectroscopy, and the DMCY was determined using reduced laboratory-scale cheese production. Factor analysis partitioned the milk components into three groups that, taken together, explain $68.3 \%$ of the total variance. The first factor was defined as "CMS", while the second as "DMCY" factor, based on their high loadings. The CMS was positively correlated with protein, casein, non-fat solids and $\alpha_{\mathrm{S}}$-casein and negatively associated with $\kappa$-casein and $\beta$-lactoglubulin. DMCY was positively correlated with fat, protein, casein, total solids and negatively correlated with $\alpha_{s}$-casein. These results indicate that the variation of individual milk proteins may be an important aspect correlated to milk quality and cheese production.
\end{abstract}

Keywords: $\kappa$-casein, $\alpha_{\mathrm{s}}$-casein, $\beta$-casein, $\alpha$-lactalbumin, $\beta$-lactoglobulin

\section{RESUMO}

O objetivo do presente estudo foi avaliar a associação das frações proteicas individuais e de outros componentes do leite com o tamanho das micelas de caseína (TMC) e a produção de matéria seca de queijo (MSQ) utilizando-se análise fatorial. Foram coletadas 140 amostras de leite de tanque provenientes de diferentes fazendas. A determinação da composição do leite foi determinada por espectroscopia no infravermelho com transformação de Fourier. As proteínas individuais ( $\alpha_{S}$-caseína, $\beta$ caseína, $\kappa$-caseína, $\beta$-lactoglobulina e $\alpha$-lactalbumina) foram quantificadas pelo perfil eletroforético. $O$ tamanho médio das micelas de caseína foi analisado pelo princípio de espectroscopia de correlação de fótons e pela produção MSQ a partir do modelo de coagulação do leite em escala reduzida. A análise fatorial delimitou as variáveis em três fatores, que, juntos, responderam por $68,3 \%$ da variação total dos dados. No primeiro fator foram observadas as associações mais fortes com o TMC, enquanto no segundo fator as correlações foram mais significativas com a MSQ. O TMC foi associado positivamente com o conteúdo de proteína, caseína, sólidos desengordurados e $\alpha_{S}$-caseína, e negativamente com $\kappa$-caseína e $\beta$-lactoglubulina. MSQ foi associada positivamente com o teor gordura, proteína e caseína total, sólidos totais, e negativamente com o teor de $\alpha_{s}$-caseína. Esses resultados indicam que a variação quantitativa das proteínas do leite pode ser determinante da qualidade do leite na produção de queijo.

Palavras-chave: $\kappa$-caseína, $\alpha_{s}$-caseína, $\beta$-caseína, $\alpha$-lactalbumina, $\beta$-lactoglobulina

Recebido em 17 de julho de 2016

Aceito em 20 de julho de 2016

E-mail: deniseribeirof@yahoo.com 


\section{INTRODUCTION}

Dry matter cheese yield (DMCY) based on a laboratory-scale model of milk enzymatic coagulation, hereby named laboratory scale cheese making (Silva et al., 2012) is a milk quality indicator of cheese yield. For this reason, DMCY might be used as an important variable for the economic outcome of the dairy industry and for genetic selection programs of dairy cows (Bittante et al., 2013). Casein micelle size (CMS) also has been reported as a possible indicator of milk quality. Smaller CMS have been shown to form a more compact and firmer gel network than larger CMS (Niki and Arima, 1984; Ford and Grandison, 1986; Walsh et al., 1998; Glantz et al., 2010). Therefore, it is possible that more nutrients are retained in the curd and increased cheese yield may be obtained from milk with lower average CMS.

Milk proteins and other milk components affect variation of DMCY and CMS. The effect of fat, total protein and casein on DMCY has been extensively studied. The prediction equations used to estimate cheese yield are normally based on the contents of milk casein and fat. For instance, fat and casein represent around $94 \%$ of the cheddar cheese dry matter (Lucey and Kelly, 1994). Although few studies have examined the effect of milk proteins on DMCY, because of analytical difficulties for determination of milk proteins, it is possible that some individual caseins play a significant role in DMCY. Wedholm et al. (2006) reported that cheese yield was improved at increasing concentrations of $\kappa$ casein $(\kappa-\mathrm{CN}), \alpha_{\mathrm{S}} 1$-casein $\left(\alpha_{\mathrm{S}} 1-\mathrm{CN}\right), \beta$-casein $(\beta$ $\mathrm{CN})$ and $\beta$-lactoglobulin ( $\beta$-LG) in milk. Hallén et al. (2010) also detected that increased $\kappa-\mathrm{CN}$ was associated with higher amount of casein retained in curd.

The correlations between CMS and milk composition, particularly the protein composition are still open to debate, because of the different results reported in the literature. The results are more consistent towards the correlation between CMS and $\kappa-\mathrm{CN}$, whereas samples with a smaller average CMS were associated with higher proportion of $\kappa-\mathrm{CN}$ in milk (McGann et al., 1980; Lodes et al., 1996; Bijl et al., 2014; Day et al., 2015).
Factor analysis is often used to reduce the dimensionality of data profiles containing intercorrelated variables (Krishnan, 2011). Because of the high number of variables that may affect DMCY and CMS, and the possibility of having significant correlation between these variables, factor analysis is a good tool to explore the associations between the studied traits. Factor analysis aims to display the maximum amount of variation in a data profile within a few principal components (Krishnan, 2011). Therefore, the aim of this study was to use factor analysis to assess the relationship between milk protein composition and others milk components with casein micelle size and dry matter cheese yield.

\section{MATERIALS AND METHODS}

Bulk tank milk samples were obtained from 140 crossbreed (Holstein x Zebu) dairy herds located in the state of Minas Gerais, Brazil. For each sample, two aliquots of milk were collected: one in a $150 \mathrm{~mL}$ sterilized flask for laboratory-scale cheese making, and the second was collected into a $50 \mathrm{~mL}$-tube and added with preservative (Bronopol, 2-bromo-2-nitropropane-1,3-diol) and used for milk quality analyses. Samples were transported at $4^{\circ} \mathrm{C}$ to the laboratory.

Fat, total protein, casein, lactose, total solids, non-fat solids, milk urea nitrogen and somatic cell count were analyzed by CombiScope FTIR $400^{\circledR} \quad$ (Delta Instruments, Drachten, The Netherlands) based on Fourier transform infrared (FTIR) for milk components and flow cytometry technology for somatic cell counting. Milk pH was measured with a digital pH-meter (DM22, Digimed, São Paulo, Brazil).

For individual protein quantification, $2 \mathrm{~mL}$ aliquots of milk were centrifuged $(2,000 \mathrm{x} \mathrm{g}, 30$ $\min , 5^{\circ} \mathrm{C}$ ) for fat removal, lyophilized, and kept at $-80^{\circ} \mathrm{C}$ until analysis. Milk proteins $\alpha_{S}-\mathrm{CN}, \beta-$ $\mathrm{CN}, \kappa-\mathrm{CN}, \alpha$-lactalbumin (LA) and $\beta$-LG were measured according to their electrophoretic mobility following the method proposed by Verdi et al. (1987) with some modifications. SDS-PAGE was carried out with a $20 \times 20 \mathrm{~cm}$ vertical cube (Prolab, São Paulo, Brazil) using $5 \%$ stacking gel in $0.5 \mathrm{M}$ Tris-HCl buffer, $\mathrm{pH} 6.8$, and $12-20 \%$ separating gels in $1.5 \mathrm{M}$ Tris- $\mathrm{HCl}$ buffer, pH 8.8 with $10 \%$ SDS. Samples (2 mg $\mathrm{mL}^{-1}$ ) were dissolved in $200 \mu \mathrm{L}$ Tris- $\mathrm{HCl}$ buffer, 
pH 6.8 with $10 \%$ SDS, 5\% $\beta$-mercaptoethanol, $5 \%$ glycerol, and bromophenol blue, and heated at $100{ }^{\circ} \mathrm{C}$ for $3 \mathrm{~min}$. Electrophoresis migration of $4 \mu \mathrm{L}$-aliquots required $4 \mathrm{~h}$ and $120 \mathrm{~V}$. Protein identification was obtained by comparison of the peaks with those obtained with five standard proteins (Sigma Aldrich, St. Louis, MO, USA): $\kappa-\mathrm{CN}$ (cat. no. C-0406), $\alpha-\mathrm{CN}$ (cat. no. C-6780), $\beta-\mathrm{CN}$ (cat. no. C-6905), $\alpha$-LA (cat. no. L-5385 type I), and $\beta$-LG (cat. no. L-4756).

The gels were suspended in a $12 \%$ trifluoroacetic acid solution for $30 \mathrm{~min}$, followed by staining with $0.1 \%$ Comassie blue R250 dissolved in a $50 \%$ ethanol and $2 \%$ acetic acid solution overnight. Destaining was accomplished in a $30 \%$ ethanol and $7.5 \%$ acetic acid solution for 12 h. Gel images were captured and processed using the software ImageJ 1.48 (NIH, Bethesda, USA) for quantification of proteins. ImageJ deconvolution was used to improve $\alpha_{\mathrm{S}}-\mathrm{CN}, \beta-\mathrm{CN}$ and $\kappa-\mathrm{CN}$ baseline curves for band quantification. $\mathrm{X}$ and $\mathrm{y}$ coordinates were analyzed using the software OriginPro8.6 (OriginLab, Northampton, USA). The relative proportion of each protein fraction was obtained as the percentage of each peak to the sum of $\alpha_{S^{-}}$ $\mathrm{CN}, \beta-\mathrm{CN}, \kappa-\mathrm{CN}, \alpha-\mathrm{LA}$, and $\beta-\mathrm{LG}$ peaks. The relative proportions of casein fractions were transformed to concentrations, based on total casein measurement by FTIR.

The average CMS was estimated by photon correlation spectroscopy (Devold, 2000) within few hours of sample collection using a Zetasizer 3000HS (Malvern Instruments Ltd., Malvern, $\mathrm{UK})$ with a He-Ne-laser set to $632.8 \mathrm{~nm}$. The samples were maintained at $25 \pm 2^{\circ} \mathrm{C}$. Parameters were unimodal measurement with $90^{\circ}$ dispersion angle at $25^{\circ} \mathrm{C}$. After fat removal by centrifugation $\left(2,000 \mathrm{x} \mathrm{g}, 30 \mathrm{~min}, 5^{\circ} \mathrm{C}\right)$, raw milk was diluted $(1: 1,000 \mathrm{v} / \mathrm{v})$ with a simulated milk ultrafiltrate (Jenness and Koops, 1962) to reach the ideal concentration indicated by the equipment manufacturer. The simulated milk ultrafiltrate was filtered $(0.22 \mu \mathrm{m})$ to avoid particles interference.

To estimate DMCY raw milk samples (25 g) were poured in $50 \mathrm{~mm}$-diameter beakers and added with $300 \mu \mathrm{L}$ of diluted acetic acid (1.1:10 $\mathrm{v} / \mathrm{v})$ for acidification, agitated for $20 \mathrm{~s}$ and kept in a water bath at $35^{\circ} \mathrm{C}$ for $10 \mathrm{~min}$. Then, acidified milk was added with $230 \mu \mathrm{L}$ of diluted rennet (HA-LA ${ }^{\circledR}$, Chr. Hansen) $(1: 10 \mathrm{v} / \mathrm{v})$, agitated for $20 \mathrm{~s}$, and kept in water bath at $35^{\circ} \mathrm{C}$ for $30 \mathrm{~min}$. Gel sample was cut in 4 uniform pieces through y-axis, transferred into a $50 \mathrm{~mL}$ tube, and centrifuged $\left(1,100 \mathrm{x} \mathrm{g}, 30 \mathrm{~min}, 10^{\circ} \mathrm{C}\right)$. Then, supernatant whey was carefully poured into a tube for weighing, whereas the precipitated gel was poured into metal plates, oven dried (100 ${ }^{\circ} \mathrm{C} \pm 2{ }^{\circ} \mathrm{C}, 4 \mathrm{~h}$ ), and weighted. DMCY was calculated as the percentage ratio of dry matter weight over the raw milk weight, as adapted from Melilli et al. (2002).

Statistical analyzes were performed with STATA statistical software version 12 (Stata Corp., College Station, 350 Texas, USA). One-way analysis of variance (one-way ANOVA) was used to compare the concentration of casein fractions between low and high average CMS. An exploratory factorial analysis of the main components, with orthogonal varimax rotation was performed to test associations among all variables surveyed together, and to investigate the possible biological meaning of associations among the individual proteins and other milk components with casein micelle size, cheese gel strength and dry matter cheese yield. Factor analysis, without pre-establishing cause/effect was used. The adequacy of the data was verified by the Kaiser-Meyer-Olkin (KMO) criteria and by the Bartlett test (Mingoti, 2005). The variables with an eingenvalue greater or equal to 1 (one) were considered relevant to the extraction of the factors. Only the items of the scale with a factor load greater than 0.50 were included as factors (Costello and Osborne, 2005).

\section{RESULTS AND DISCUSSION}

Descriptive statistics for the investigated traits are reported in Table 1.

Factor analysis partitioned the milk components into three groups (Table 2) that together explain $68.3 \%$ of the variance. The first factor explained $33.4 \%$, the second explained $18.1 \%$, and the third $16.7 \%$ of the total variance. The first factor was defined "CMS", while the second was "dry matter cheese yield", because in the first factor the high loadings $(>0.5)$ are linked to CMS, while in the second factor the high loadings are linked to DMCY. 
Table 1. Descriptive statistics for the investigated traits

\begin{tabular}{|c|c|c|c|c|}
\hline Variables & Average & SD & Minimum & Maximum \\
\hline Casein micelles average size $(\mathrm{nm})$ & 183.16 & 11.53 & 157.80 & 208.40 \\
\hline \multicolumn{5}{|l|}{ Composition, SCC, pH } \\
\hline Fat $(g / 100 g)$ & 3.57 & 0.43 & 2.46 & 4.66 \\
\hline Protein $(\mathrm{g} / 100 \mathrm{~g})$ & 3.23 & 0.17 & 2.96 & 3.65 \\
\hline Casein $(g / 100 g)$ & 2.50 & 0.14 & 2.27 & 2.85 \\
\hline Casein number, $\%^{1}$ & 77.41 & 0.91 & 75.16 & 79.06 \\
\hline Lactose $(\mathrm{g} / 100 \mathrm{~g})$ & 4.44 & 0.13 & 4.06 & 4.69 \\
\hline $\operatorname{Urea}(\mathrm{mg} / \mathrm{dL})$ & 22.35 & 10.83 & 7.50 & 54.10 \\
\hline $\mathrm{SCC}^{2}$ & 5.23 & 1.07 & 1.49 & 7.41 \\
\hline $\mathrm{pH}$ & 6.67 & 0.16 & 6.31 & 7.22 \\
\hline \multicolumn{5}{|c|}{ Protein fractions ${ }^{3}$ (based on total casein measured by FTIR) } \\
\hline$\alpha_{\mathrm{s}}-\mathrm{CN}^{4}(\mathrm{~g} / 100 \mathrm{~mL})$ & 1.58 & 0.18 & 1.28 & 2.06 \\
\hline$\beta-\mathrm{CN}(\mathrm{g} / 100 \mathrm{~mL})$ & 0.62 & 0.11 & 0.40 & 0.89 \\
\hline $\mathrm{k}-\mathrm{CN}(\mathrm{g} / 100 \mathrm{~mL})$ & 0.30 & 0.09 & 0.12 & 0.46 \\
\hline \multicolumn{5}{|c|}{ Relative composition of proteins (as \% of total protein measured by eletrophoresis) } \\
\hline$\alpha_{\mathrm{s}}-\mathrm{CN}^{4}$ & 53.91 & 6.41 & 40.64 & 68.50 \\
\hline$\beta-\mathrm{CN}$ & 21.30 & 3.99 & 12.95 & 31.66 \\
\hline $\mathrm{k}-\mathrm{CN}$ & 10.10 & 2.89 & 4.47 & 15.27 \\
\hline$\beta-\mathrm{LG}$ & 10.36 & 3.62 & 4.48 & 20.83 \\
\hline$\alpha-\mathrm{LA}$ & 4.33 & 1.39 & 2.01 & 7.86 \\
\hline \multicolumn{5}{|l|}{ Technological indicators } \\
\hline Cheese gel strength ( $\mathrm{G}$ force) & 10.11 & 1.79 & 6.70 & 13.50 \\
\hline Dry matter cheese yield, $\%$ & 7.22 & 0.84 & 5.35 & 9.67 \\
\hline
\end{tabular}

SCC: somatic cell count; TBC: total bacteria count; FTIR: Fourier transform infrared; CN: casein; LG: lactoglobulin. LA: lactalbumin. ${ }^{1}$ Casein number $=($ casein/protein $) \times 100 ;{ }^{2} \mathrm{SCS}=\log _{2}(\mathrm{SCC} / 100)+3 ;{ }^{3} \mathrm{Calculated}$ based on milk total casein obtained by FTIR; ${ }^{4} \alpha \mathrm{s} 1-\mathrm{CN}+\alpha \mathrm{s} 2-\mathrm{CN}$.

Table 2. Associations among individual proteins and other milk quality components with casein micelle size and dry matter cheese yield expressed as loadings in a principal components analysis

\begin{tabular}{|c|c|c|c|}
\hline Variables & Factor 1 & Factor 2 & Factor 3 \\
\hline Dry matter cheese yield, \% & -0.1623 & 0.6859 & 0.4216 \\
\hline Casein micelles size average $(\mathrm{nm})$ & 0.5775 & -0.2589 & -0.1432 \\
\hline Fat $(g / 100 g)$ & 0.4792 & 0.5923 & 0.1075 \\
\hline Protein $(g / 100 g)$ & 0.6290 & 0.5483 & 0.2195 \\
\hline Casein $(g / 100 g)$ & 0.6140 & 0.6252 & 0.2568 \\
\hline Non-fat solids $(\mathrm{g} / 100 \mathrm{~g})$ & 0.8240 & 0.2368 & 0.0754 \\
\hline Total solids $(\mathrm{g} / 100 \mathrm{~g})$ & 0.5963 & 0.6890 & 0.1894 \\
\hline Somatic cell count (cells/mL) & -0.2022 & 0.1287 & 0.0490 \\
\hline Total bacterial count & -0.0818 & -0.0888 & 0.0544 \\
\hline$\alpha_{\mathrm{s}}-\mathrm{CN}^{4}(\mathrm{~g} / 100 \mathrm{~mL})$ & 0.7554 & -0.5010 & 0.3882 \\
\hline$\beta-\mathrm{CN}(\mathrm{g} / 100 \mathrm{~mL})$ & -0.2872 & 0.4442 & -0.8305 \\
\hline $\mathrm{k}-\mathrm{CN}(\mathrm{g} / 100 \mathrm{~mL})$ & -0.8255 & 0.2381 & 0.4087 \\
\hline$\alpha_{\mathrm{s}}-\mathrm{CN}(\%$ total protein $)$ & 0.8482 & -0.4276 & 0.1138 \\
\hline$\beta-\mathrm{CN}(\%$ total protein) & -0.0955 & 0.3882 & -0.9059 \\
\hline $\mathrm{k}-\mathrm{CN}$ (\% total protein) & -0.7840 & 0.2314 & 0.3672 \\
\hline$\beta$-LG ( $\%$ total protein) & -0.5946 & 0.1956 & 0.2506 \\
\hline$\alpha$-LA ( $\%$ total protein) & -0.4537 & -0.1345 & 0.6558 \\
\hline Variance explained (\%) & 33.42 & 18.14 & 16.70 \\
\hline
\end{tabular}

CN: casein; LG: lactoglobulin; LA: lactalbumin. 
Factor 1 had loadings higher than 0.5 for average CMS, protein, casein, non-fat-solids, total solids, $\alpha_{\mathrm{S}}-\mathrm{CN}, \mathrm{k}-\mathrm{CN}$ and $\beta$-LG. CMS is positively correlated with protein, casein, non-fat solids, total solids and $\alpha_{S}-\mathrm{CN}$ whereas, CMS was negatively correlated with $\mathrm{k}-\mathrm{CN}$ and $\beta$-LG. The positive correlation between CMS and total protein and casein content is explained by the fact that casein micelles are formed by thousands of individual proteins molecules associated with calcium phosphate (de Kruif, 1998) and are found in various ratios as shown in Tab. 1. For instance, $\alpha_{\mathrm{S}}-\mathrm{CN}$ is responsible for about $50 \%$ of the total casein, and it is the protein fraction with a higher concentration on both the total casein and protein contents. Probably, the positive correlation between total protein and casein content may be due to the high concentration of $\alpha_{\mathrm{S}}-\mathrm{CN}$ in milk.

Day et al. (2015) also described that $\alpha_{\mathrm{S}}-\mathrm{CN}$ was associated with higher CMS in milk of individual cows. Conversely, Dalgleish and Corredig (2012), Bijl et al. (2014) and de Kruif and Huppertz (2012) did not observe any difference in $\alpha_{S}-C N$ content in milk samples with smaller and larger CMS.

The negative association between CMS and $\kappa$ $\mathrm{CN}$ are in agreement with studies that have shown that smaller CMS are relatively rich in $\kappa$ CN (Dalgleish et al., 1989; Dalgleish and Corredig, 2012). Most, if not all, $\kappa-\mathrm{CN}$ molecules are located on the micelle surface (Dalgleish et al., 1989), so this amount is related to the ratio of volume and surface area of the micelles. The $\kappa-\mathrm{CN}$ outer layer, particularly the glycosylated molecules, is primarily responsible for the steric and electrostatic repulsive forces between micelles. The exact mechanism that provides this difference is still not fully clear. With this in mind, European cow breeds that have $\mathrm{KCN}$ AA genotype tend to produce milk with larger casein micelles than animals with $\mathrm{CN}$ $\mathrm{K}-\mathrm{AB}$ or BB genotype (Lodes et al., 1996; Walsh et al., 1998; Ng-Kwai-Hang et al., 2002; Glantz et al., 2010; Bijl et al., 2014). Freitas et al. (2015) evaluated the CMS of milk samples from different proportions of Holstein $\mathrm{x}$ Zebu crossbreeding ratios, and observed that animals with higher ratio of Zebu produce milk with lower average CMS. Only a few studies about the effect of crossbreeding on CMS are available and more are necessary to better understand the genetic factors that interfere on the CMS, which can provide improvements in the production of dairy products.

The negative correlation between CMS and $\kappa$ $\mathrm{CN}$ content has been widely reported in bulk milk where micelles were fractionated to different sizes (Davies and Law, 1983; Dalgleish et al., 1989), as found here in individual cow's milk. However, some recent studies (de Kruif and Huppertz, 2012; Bijl et al., 2014) on milks from individual cows found no statistically significant differences between CMS and the relative amount of $\kappa-\mathrm{CN}$ to total proteins.

To determine to what extent casein fractions contribute to CMS, these values were divided in two groups of 40 samples each. The groups were selected based on smaller $(156.6-177.7 \mathrm{~nm})$ and larger (189.9 - 209.7) CMS. Significant differences in the levels of $\alpha_{S}-\mathrm{CN}$ and $\kappa-\mathrm{CN}$ between the two groups were found (Tab. 3). The group with larger CMS had $2.18 \mathrm{~g} / \mathrm{L}$ more of $\alpha_{\mathrm{S}^{-}}$ $\mathrm{CN}$ than the group with smaller CMS, while the difference of concentration of $\kappa-\mathrm{CN}$ between these groups was $1.11 \mathrm{~g} / \mathrm{L}$. No statistical differences on the $\beta$ - $\mathrm{CN}$ concetration between these groups were found (Tab. 3) which is similar to recent findings of Day et al. (2015).

Table 3. The concentrations of individual caseins to total casein based on casein micelles size

\begin{tabular}{lccc} 
& \multicolumn{2}{c}{ Casein micelle size group } & \\
\cline { 2 - 3 } Casein $(\mathrm{g} / \mathrm{L})$ & Small & Large & $P$-value \\
\hline$\alpha_{\mathrm{s}}$-casein & $14.59 \pm 1.10$ & $16.77 \pm 1.97$ & $<0.001$ \\
$\beta$-casein & $6.42 \pm 1.12$ & $6.08 \pm 1.12$ & 0.18 \\
$\kappa$-casein & $3.61 \pm 0.48$ & $2.50 \pm 0.75$ & $<0.001$ \\
\hline
\end{tabular}

Factor 2 had loadings higher than 0.5 for dry matter cheese yield (DMCY), fat, protein, casein, total solids and $\alpha_{\mathrm{s}}-\mathrm{CN}$ (Tab. 2). DMCY was positively correlated with fat, protein, casein, total solids and negatively correlated with $\alpha_{\mathrm{s}}-\mathrm{CN}$. The positive association of increased fat and casein with DMCY have been previously reported by Verdier-Metz et al. (2001) and 
Bittante et al. (2013). Milk compostion is the main factor that affects cheese yield, especially the fat and casein contents, that together are responsible for the major portion of the cheese dry matter. This phenomena is due to the fact that casein forms a mesh of paracasein that retains mainly fat, moisture and other minor constituents during the process of production of cheese. Regarding that, several mathematical formulas were developed to predict the production of cheese, considering fat and casein contents from milk as the main coefficients that account for the DMCY (Lucey and Kelly, 1994).

In factor 2, among all protein fractions analyzed, the $\alpha_{\mathrm{s}} \mathrm{CN}$ was the unique protein fraction that had a loading higher than $0.5(-0.5010)$. The negative value indicated that $\alpha_{\mathrm{s}}-\mathrm{CN}$ and DMCY are negatively correlated. There is not a clear explanation for this negative correlation. Bonfatti et al. (2011) showed that milk samples with higher $\alpha_{\mathrm{s}}-\mathrm{CN}$ content had lower milk clotting time and lower gel strength. These variables are commonly used as indicators of the quality of milk for cheese production. These authors have also suggested that the increase in $\beta-\mathrm{CN}$ and $\kappa$ $\mathrm{CN}$ contents and a decrease in the $\alpha_{\mathrm{s}}-\mathrm{CN}$ by genetic selection of animals can be a tool to improve the milk clotting characteristics. In our study, the loading for $\beta-\mathrm{CN}$ and $\kappa-\mathrm{CN}$ was not higher than 0.5 , although there was a positive association between these variables $(0.4442$ for $\beta-\mathrm{CN}$ and 0.2314 for $\kappa-\mathrm{CN}$ ) and the DMCY (Tab. 2).

The unique protein fraction with a loading higher than 0.5 for both DMCY and CMS was $\alpha_{\mathrm{s}}-\mathrm{CN}$. On the other hand, $\kappa-\mathrm{CN}$ content was associated with smaller CMS and a higher DMCY similar to the findings of Bonfatti et al. (2011), which described that these two protein fractions have opposite effects on cheese yield.

Factor 3 had loadings higher than 0.5 only for $\beta$ $\mathrm{CN}$ and $\alpha$-LA (Tab. 2), which suggested that these two milk proteins has no significant association with CMS and DMCY. These outcomes are in agreement with the results showed in Tab. 3, where there is no significant diference on the $\beta-\mathrm{CN}$ concentration between the group with small and large CMS. The $\alpha$-LA is a whey protein, and as a result $\alpha$-LA did not constitute the casein micelle structure, and consenquently explain the absence of association with CMS and DMCY.

To the best of our knowledge, this is the first work that investigated the relationship between milk protein fractions and DMCY and CMS using factor analysis. With this statistical tool, it was possible to evaluate the association of all the relevant variables and variation of CMS and DMCY. A factor analysis for the main associations between CMS and milk composition and protein fractions was designed. Another factor which establishes the associations between DMCY and milk composition and the protein fractions was estimated. In addition to all associations above discussed, the definition of the these factors showed that CMS is most strongly associated with the individual protein fractions, while the DMCY is most affected by the milk composition (fat, total protein, total casein and total solids), as well as, it is strongly associated with $\alpha \mathrm{s}-\mathrm{CN}$ concentration.

\section{CONCLUSION}

The CMS was associated with individual milk proteins, particularly $\alpha_{S}$-casein and $\kappa$-casein, while DMCY was associated with fat, total protein, total casein, total solids and $\alpha_{S}$-casein contents. These results indicate that the variation of individual milk proteins, and not only the total protein, may be crucial to determine milk quality and cheese yield.

\section{REFERENCES}

BIJL, E.; DE VRIES, R.; VAN VALENBERG, H. et $a l$. Factors influencing casein micelle size in milk of individual cows: genetic variants and glycosylation of к-casein. Int. Dairy J., v.34, p.135-41, 2014.

BITTANTE, G.; CIPOLAT-GOTET, C.; CECCHINATO, A. Genetic parameters of different measures of cheese yield and milk nutrient recovery from an individual model cheese-manufacturing process. J. Dairy Sci., v.96, p.7966-7979, 2013.

BONFATTI, V.; CECCHINATO, A.; GALLO, L. et al. Genetic analysis of detailed milk protein composition and coagulation properties in Simmental cattle. J. Dairy Sci., v.94, p.5183-93, 2011.

COSTELLO, A.B.; OSBORNE, J.W. Best practices in explanatory factor analysis: four recommendations for getting the most from your analysis. Pract. Assess. Res. Evaluation, v.10, p.1-8, 2005. 
DALGLEISH, D.G.; CORREDIG, M. The structure of the casein micelle of milk and its changes during processing. Annu. Rev. Food Sci. Technol., v.3, p.44967, 2012.

DALGLEISH, D.G.; HORNE, D.S.; LAW, A.J.R. Size-related differences in bovine casein micelles. BBA Gen. Subjects, v.991, p.383-387, 1989.

DAVIES, D.T.; LAW, A.J.R. Variation in the protein composition of bovine casein micelles and serum casein in relation to micellar size and milk temperature. J. Dairy Res., v.50, p.67-75, 1983.

DAY, L.; WILLIAMS, R.P.W.; OTTER, D.; AUGUSTIN, M.A. Casein polymorphism heterogeneity influences casein micelle size in milk of individual cows J. Dairy Sci., v.98, p.3633-3644, 2015.

DE KRUIF, C.G. Supra-aggregates of casein micelles as a prelude to coagulation. J. Dairy Sci., v.81, p.30193028, 1998.

DE KRUIF, C.G.; HUPPERTZ, T. Casein micelles: size distribution in milks from individual cows. $J$. Agric. Food. Chem., v.60, p.4649-4655, 2012.

DEVOLD, T.G. Size of native and heated casein micelles, content of protein and minerals in milk from norwegian red cattle - effect of milk protein polymorphism and different feeding regimes. J. Dairy Res., v.10, p.313-323, 2000.

FORD, G.D.; GRANDISON, A.S. Effect of size of casein micelles on coagulation properties of skim milk. J. Dairy Res., v.3, p.129-33, 1986.

FREITAS, D.R.; FONSECA, L.M.; SOUZA, F.N. et al. Influence of race and crossbreeding on casein micelles size. Anim. Sci. J., v.86, p.553-556, 2015.

GLANTZ, M.; DEVOLD, T.G.; VEGARUD, G.E. et al. Importance of casein micelle size and milk composition for milk gelation. J. Dairy Sci., v.93, p.1444-1451, 2010.

HALLÉN, E.; LUNDÉN, A.; ALLMERE, T.; ANDRÉN, A. Casein retention in curd and loss of casein into whey at chymosin-induced coagulation of milk. J. Dairy Res., v.77, p.71-76, 2010.

JENNESS, R.; KOOPS, J. Preparation and properties of a salt solution which simulates milk ultrafiltrate. Milk Dairy J., v.15, p.64, 1962.

KRISHNAN, V.A comparison of principal components analysis and factor analysis for uncovering the early development instrument (EDI) domains. Edmonton: Community-University Partnership, 2011.52p
LODES, A.; KRAUSE, I.; BUCHBERGER, J. et al. The influence of genetic variants of milk proteins on the compositional and technological properties of milk. 1. Casein micelle size and the content of nonglycosylated kappa-casein. Milchwissenschaft, v.51, p.368-373, 1996.

LUCEY, J.; KELLY, J. Cheese yield. Int. J. Dairy Technol., v.47, p.1-14, 1994.

MCGANN, T.C.; DONNELLY, W.J.; KEARNEY, R.D.; BUCHHEMM, W. Composition and size distribution of bovine casein micelles. BBA Gen. Subjects, v.630, p.261-270, 1980.

MELILLI, C.; LYNCH, J.M.; CARPINO, S. et al. An empirical method for prediction of cheese yield. $J$. Dairy Sci., v.85, p.2699-2704, 2002.

MINGOTI, S.A. Análise de dados através de métodos de estatística multivariada. Belo Horizonte: UFMG, 2005. 295p.

NG-KWAI-HANG, K.F.; OTTER, D.E.; LOWE, E. et $a l$. Influence of genetic variants of $\beta$-lactoglobulin on milk composition and size of casein micelles. Milchwissenschaft, v.57, p.303-306, 2002.

NIKI, R.; ARIMA, S. Effects of size of casein micelle on firmness of rennet curd. Jpn. J. Zootec. Sci., v.55, p.409-415, 1984.

SILVA, N.M.A.; BASTOS, L.P.F.; OLIVEIRA, D.L.S. et al. Influence of somatic cell count and total bacteria counts of raw milk in cheese yield using small-scale methodology. Arq. Bras. Med. Vet. Zootec., v.64, p.1367-1372, 2012.

VERDI, R.J.; BARBANO, D.M.; DELLAVALLE, M.E.; SENYK, G.F. Variability in true protein, casein, nonprotein nitrogen, and proteolysis in high and low somatic cell milks. J. Dairy Sci., v.70, p.230-242, 1987.

VERDIER-METZ, I.; COULON, J.B.; PRADEL, P. Relationship between milk fat and protein contents and cheese yield. Anim. Res., v.50, p.365-371, 2001.

WALSH, C.D.; GUINEE, T.P.; REVILLE, W.D. et al. Influence of $\kappa$-casein genetic variant on rennet gel microstructure, cheddar cheesemaking properties and casein micelle size. Int. Dairy J., v.8, p.707-714, 1998.

WEDHOLM, A.; LARSEN, L.B.; LINDMARKMANSSON, H. et al. A. Effect of protein composition on the cheese-making properties of milk from individual dairy cows. J. Dairy Sci., v.89, p.32963305, 2006. 